\title{
Exhibition Service Quality and Its Influence to Exhibitor Satisfaction
}

\author{
Adhitya, Bagus Githa \\ Event \& Convention Management \\ Sekolah Tinggi Pariwisata Bandung \\ Bandung, Indonesia \\ baa@stp-bandung.ac.id
}

\begin{abstract}
Convention \& Exhibition is the fastest growing segment of the tourism market. Service quality is an important component to achieve satisfaction in the exhibition industry. The fate of the exhibition in the future depends on the satisfaction of the exhibitor of the exhibition services quality. The purpose of this study is to measure the level of exhibitors satisfaction towards the exhibition service quality of the organizers, and to determine the effect of each dimension of the exhibition services quality that affecting the exhibitor's satisfaction. Another major contribution of this research is that it can be a scientific recommendation for organizers to prepare for the next event and can also serve as a guidance framework for measuring exhibitors' satisfaction at trade fairs / trade shows.
\end{abstract}

The focus of this research is PT Dyandra Promosindo, which helds an exhibition of Indonesia Future City and REI Mega Expo 2017. The research data is obtained from a sample of 73 exhibitors who participated in the exhibition.

This research uses descriptive verification statistic analysis to find out the service quality given by organizer, IPA (Importance Perfomance Analysis) to find out the satisfaction of exhibitors through expectation and perception perspective, and Multiple Regression Analysis to find out the influence between variables. $X$ as independent variable is Exhibition Service Quality which includes exhibition marketing, exhibition design, stand management, environment, service information and services personnel and $Y$ as dependent variable is exhibitors satisfaction.

The results show that the exhibition service quality is considered very important in terms of expectations and quite good from the perception, meanwhile for satisfaction it can be seen that there are some indicators that are considered not able to satisfy the exhibitors. Quadrant A (Main Priority) there are 14 indicators, Quadrant B (Maintain Achievement) there are 10 indicators, Quadrant $C$ (Lowest Priority) there are 3 indicators and Quadrant $D$ (Category Overload) there are 13 indicators. $T$ test results (Partial Test) and Test $F$ (Simultaneous Test) found that the attributes of exhibition marketing and the environment influence partially to the exhibitors satisfaction. While the six attributes in the exhibition service quality simultaneously affect the exhibitors satisfaction.

Keywords-exhibition, exhibition service quality, exhibitor satisfaction

\section{INTRODUCTION}

Convention \& Exhibition is the fastest growing segment of the tourism market ((Kim, Sun, \& Ap, 2008). Based on data from the Global Exhibition Industry Statistics issued by UFI (The Global Association of the Exhibition Industry) in 2016, it is estimated that around 31,000 exhibitions staged around the world each year, with 124 million sqm space successfully leased to 4.4 million exhibitors, and were visited by 260 million visitors.

Previous studies show that exhibition is one of the effective activities in order to bring together exhibitors and visitors (Getz, 2008; Kozak, 2006; and Pearce, 2007).

The results of previous studies also present that an exhibition can be run well, if there are players consisting of organizers, exhibitors, and visitors (Bruhn \& Hadwich, 2005). In addition, the organizer is also responsible for the implementation of an exhibition by providing services to exhibitors and visitors (Jin \& Weber, 2016)

In the present exhibition industry, the organizer provides services to exhibitors and visitors, not only during the exhibition, but also before and after the exhibition. They also conduct promotional activities to bring visitors who are desired by the exhibitors. (Smith, Pest, \& Smith, 2003). In addition, the organizer has to create interesting objectives for both parties (Jin \& Weber, 2016).

Future City \& REI Mega Expo 2017 was chosen by the author as the location of the study because the Housing and Settlement Development Sector became one of the national development priorities and targets in 2017 which was proclaimed by the government, with target ownership plan of 4.4 million units by the end of 2019 (Bappenas, 2016)

Indonesia Future City \& REI Mega Expo 2017 was held by PT. Dyandra Promosindo collaborates with the DPI REI (Board of Management of the Indonesian Center for Real Estate Association), APEKSI (Association of Indonesian City Governments), APKASI (Association of District Governments throughout Indonesia) and was supported by the Ministry of Public Works \& Housing of Indonesia. This exhibition was held for the first time with the aim of supporting government programs in providing decent housing for the community. The exhibition was held at ICE BSD starting from September 14-24, 2017. In its implementation, the exhibition successfully brought 90 exhibitors and 29,000 visitors, with an estimated total transaction made during the exhibition of Rp. 673,973,466,051.

Exhibitors are main target customers for organizers. Therefore, the success of exhibitions depends on the number of exhibitors at the exhibition. The exhibition exists because they serve exhibitors' needs. Once the exhibition stops 
satisfying the needs of the exhibitor, the demand for exhibition would disappear (Tanner, Chonko, \& Ponzurick, 2001). Thus, finding new ways to attract exhibitors to participate again in the next exhibition is a challenging thing for the organizer (Gofman et al., 2011). The fate of the exhibition in the future depends on the exhibitors' satisfaction of the exhibition services quality and their intention to re-visit (George, 2012; Jung, 2005). Therefore, understanding exhibitors' perception of the exhibition services quality and their influence on exhibitors' satisfaction can help the organizer to better understand the needs of the exhibitor (Lee et al., 2012), and also provide meaningful input for the organizer (Lee et al., 2015).

George (2012) argued that the exhibition services quality is closely related to the experience of the exhibitors, which means it is also important for the quality of interaction with visitors at the event. Like customers in other industries, exhibitors' perception towards the exhibition service quality can substantially affect the level of satisfaction.

From the results of preliminary observations made by the author during the exhibition, it was seen that there were very few visitors who came to the exhibition and there were many complaints from the exhibitors, so the author suspected that there was dissatisfaction with the exhibitors regarding the services provided by the organizer.

Due to the limit of the research about this topic and considering the importance of this topic in the development of the exhibition industry in Indonesia, the purpose of this study is to measure the level of exhibitors' satisfaction towards the exhibition service quality of organizers, and to determine the effect of each dimension of the exhibition service quality that affecting the exhibitors' satisfaction. Another major contribution of this study is that it can be a scientific recommendation for the organizer to prepare for the upcoming event and can be a guiding framework in measuring exhibitor satisfaction in the Indonesian exhibition industry, especially for ASPERAPI members.

High quality of exhibition services will result satisfaction and loyalty, willingness to recommend to others, and reduction in complaints (Wu, Cheng, \& Ai, 2016; Esu, 2014; Levesque \& McDougall, 1996).

Yuan and Jang (2008) argued that satisfaction is the holistic reaction towards products and services. While Esmailpour, Zadeh \& Hoseini (2012) described satisfaction as a consumer assessment that combines cognitive and affective evaluation after their consumption experience. According to $\mathrm{Wu}$, Cheng \& $\mathrm{Ai}$ (2016) there is a positive relationship between the exhibition service quality towards satisfaction.

Both exhibitor and visitor are customers for PEO, who need to be served well in orde rto satisfy their customers, so the services provided by PEO must have a quality (Jin \& Weber, 2016). Service quality is an important component for achieving satisfaction in the exhibition industry (Wu, Cheng, Ai, 2016).

From the explanation above, it can be devised that the exhibitors' dissatisfaction is affected by the exhibition service quality of the organizer.
Meanwhihe variable of the Exhibition Service Quality discussed in this study covers 6 aspects, they are exhibition marketing, exhibition design, surrounding environment, service personnel, booth management, and service information. While the exhibitor's satisfaction dimensions are reviewed in its entirety.

This study seek to identify some problems as follows:

1. How is the exhibition service quality in Indonesia Future City \& REI Mega Expo 2017?

2. How is the level of exhibitors' satisfaction in Indonesia Future City \& REI Mega Expo 2017?

3. How is the effect of the exhibition service quality towards exhibitors' satisfaction in Indonesia Future City \& REI Mega Expo 2017?

Thus the purpose of this study is to measure the level of exhibitors' satisfaction towards the exhibition service quality of organizers, assess exhibitors' satisfaction and the effect of each dimension of the exhibition service quality that affecting the exhibitors' satisfaction.

\section{LITERATURE REVIEW}

Research in service marketing reveals that service quality and satisfaction are closely related constructs. Many empirical studies have concluded that perceived service quality directly affects satisfaction (Ok, Back \& Shanklin, 2006; E.W. Anderson \& Sullivan, 1993; Oliver \& DeSarbo, 1988; Churchill \& Suprenant, 1982).

Although the literature has explored the causal relationship among these constructs, empirical support for these relationships in the exhibition industry, particularly from the perspective of exhibitor, is very limited. Thus, we must review existing exhibition research on exhibitors and apply findings to the proven service quality-satisfaction framework.

\section{EXHIBITION SERVICE QUALITY}

Service quality is the consumer's evaluation of a product's overall excellence or superiority (Parasuraman, Zeithaml, \& Berry, 1985). In spite of the debate about how to operationalize service quality, most researchers agree that perceived quality is the cognitive response to a service experience and that the approach to develop the measurements of service quality (i.e., the perception minus expectation approach and the perceptions only approach) depends on the study's purpose (Petrick, 2004). For instance, if the purpose of study is to explain variance in dependent constructs, the perceptions-only approach is appropriate (Parasuraman, Zeithaml, \& Berry, 1994). Customer satisfaction and postpurchase behaviors are influenced by the quality of customer service, so provided quality service has become a major concern in all hospitality businesses.

Since Parasuraman, Zeithaml, and Berry (1988) introduced a 22-item scale in five categories (reliability, tangibles, responsiveness, assurance, and empathy), called SERVQUAL, for measuring service quality; the framework has been widely adopted across industries (Oh, 1999). Although this theory-based approach to measure service quality has improved marketers' understanding of 
consumers' purchase behaviors, the applicability of SERVQUAL dimensions to the hospitality industry has only limited support (Oh, 1999). Notable empirical efforts have attempted to refine the traditional SERVQUAL measurements to better reflect the unique components of hospitality consumption experiences. In the foodservice sector, the DINESERV (Stevens, Knutson, \& Patton, 1995) was developed as a derivative of SERVQUAL to determine how customers view restaurant service quality. Similarly, in the lodging sector, Getty and Thompson (1994) introduced the LODGQUAL for assessing hotel service quality, using similar dimensions of SERVQUAL. However, comparatively little research has focused on developing service quality management in the exhibition industry, which is surprising given the size of the industry and its economic impact on local and national economies and given that in the exhibition industry, show organizers and venue managers provide various services that affect exhibitor satisfaction and eventually their future behaviors (M. Lee, 2007).

\section{METHODOLOGY}

The data used in this study were primary and secondary data. Primary data was obtained from questionnaires distributed to exhibitors that participated in the exhibition, while secondary data was obtained through literature studies and initial interviews with the organizers. The research instrument has been tested for validity and reliability first, then analyzed using descriptive analysis method, Importance Performance Analysis (IPA) and multiple linear regression. The population of this study were exhibitors that participated in the exhibition, which were 90 companies, with a minimum sample number according to Krejcie \& Morgan is 73.

\section{EMPIRICAL RESULTS AND DISCUSSIONS}

A. Respondents Profile

The exhibitors who participated in this exhibition were mostly quartered in DKI Jakarta (57.53\%), with developer as the majority of business scope (58.90\%), $41.10 \%$ having a workforce of $>100$ people, and $36.99 \%$ employing 6-10 employees. Furthermore, Job Position of the respondents who filled out the questionnaire was dominated by the Manager (34.25\%) and mostly from marketing division $(54.79 \%)$.

\section{B. Exhibition Service Quality}

The exhibition service quality provided by PT. Dyandra Promosindo as the organizer of the Indonesia Future City \& REI Mega Expo 2017 must have a quality, especially for its customers; exhibitors and visitors. In this study the main focus is the exhibition quality services that are expected and perceived by the exhibitors.

Expectation attribute of exhibition service quality, with a total of 40 questions and 73 respondents, obtained a total score of 12662.The length of the interval for each category is 2336 , and is in the interval range between 12264 and 14600. Based on the total score of responses from the respondents regarding the expectations of exhibition service quality that affect the satisfaction of exhibitors considered as Very Important

Meanwhile perception attribute of exhibition service quality, with a total of 40 questions and 73 respondents, obtained a total score of 9842 . The length of the interval for each category is 2336 , and is in the interval range between 7592 and 9928. Based on the total score of responses from the respondents regarding the perception of exhibition service quality that affect the satisfaction of exhibitors considered as Fairly Good.

Based on the theoretical concepts raised and elaborated in the operational variables of this study, there are six attributes of the exhibition service quality.

Exhibition marketing attribute relates to the efforts made by the organizer in marketing activities which include aiming to provide information about products / services, affect purchasing decisions, create economic value of a product / service, and to bring visitors. In this study the focus in the exhibition marketing attribute of the exhibition is how the promotion methods conducted by the organizer in bringing visitors, so that the indicators under study are more focused on that. The indicators in the exhibition marketing are as follows: Promotion of mass media, promotion via invitation, promotion through print media, promotion via internet, number of visitors, and transactions made by visitors.

The assesment by respondents' expectation towards the exhibition service quality in the exhibition marketing attribute obtained a total score of 1993, considered as very important. While respondents' perception towards the exhibition service quality in the exhibition marketing attribute obtained a total score of 1200 , considered as bad. The most critical indicators of dissatisfaction of the exhibitors are the number of visitors and transactions made by visitors. They assesed that the number of visitors who came to this exhibition were very few.and the direct transactions made by the visitors are very minimum, although the duration of the exhibition was actually quite long, ie 10 (ten) days.These results indicate that exhibition marketing attribute was very important for exhibitors, as a matter of fact, they had high expectation of this attribute, yet their perceptions toward it considered as bad. Indeed this issue must be well considered by the organizer for planning and excecuting the next similar exhibition.

Based on the interviews with the organizer, they actually have carried out promotional methods that are quite comprehensive using various media,Such as collaborated with various mass media both print and electronic to advertise and hold coverage in Venue Magazine, Marketing, Property-in, Info Gading Group, Venuemagz.com, Liputan6.com, Katalogpromosi.com, Infonitas.com, Winnetnews.com, rumah123.com, Eventjakarta.com, Rumahku.com, Housing-estate.com, Kompas.com, Kompas Gramedia Ads, Koran Jakarta, Warta Kota, Media Indonesia, Radio Sonora, Smart FM, Sonora Bandung, Motion FM, Music City, Indika FM, 
Woman Radio, Music City Fm, TV Commercial (Kompas TV, Airporteve, Lini Kini-Commuter Line); collaborated with the exhibitors by sending invitations to potential buyers / visitors; Distributed print media at various points around Jakarta, Tangerang, Depok, Bekasi and Bogor; created a special website for the exhibition; cooperated with REI (Real Estate Indonesia) association, Sinarmas Land, BTN, BRI and BNI by sending broadcast invitations of the exhibition to their clients.

As the first property exhibition held by PT. Dyandra Promosindo, it is tremendously a challenge in its planning and implementation. The experience in planning and organizing a new exhibition certainly requires tremendous effort. If we see and analogize this exhibition as a product, then this exhibition falls into the Introductory Stage category in a product cycle. This introductory stage shows that the marketed products are completely new, hence the public does not know or recognize them yet, so it takes an effort to introduce that exhibition to the community through the delivery of information by conducting promotional activities aggressively to emphaze the sales brand (exhibition's name), the value compared to other similar exhibitions, or more benefits that visitors will receive. This introductory phase usually requires a very large promotional budget and cooperation with stakeholders, and appropriate media to achieve the goals. The use and selection of the right promotional media in organizing an exhibition certainly varies from one type of exhibition to another

The exhibitors agreed that a large number of visitors will certainly increase the chances of transactions. They believe that the exhibition is an alternative platform to sell their products / services to potential customers. This is compounded by the fact that the exhibitors pay the booth rental fee to be able to take part in exhibitions, as well as various discount programs so they assume that the costs they have incurred must be returned from the transactions made by the visitors. These are some of the basics asumptions that lead to dissatisfaction with exhibitors toward the exhibition service quality, especially the exhibition marketing attribute.

The next attribute is about exhibition design. The indicators in this attribute are: Design of promotional materials, venue decoration, logo, and ideas \& concepts design. This attribute referes to aspects related to the visual and graphic design of exhibition material.

The assesment by respondents' expectation towards the exhibition service quality in the exhibition deisgn attribute obtained a total score of 1234 , considered as very important. While the respondents' perception towards the exhibition service quality in the exhibition design attribute obtained a total score of 973, considered as fairly good. The majority of respondents agreed that the overall exhibition design was appealing and also suitable to the theme and concept of the event.

In the case of designing concepts, PT. Dyandra Promosindo is considered to have succeeded in creating several design themes that are in line with the concept of the exhibition.Beside of that, some designs have been personalized with the uniqueness and needs of the sponsors and exhibitors. The variety of visualization design also became one of the added values for the exhibition, especially in terms of attracting people to visit the event. Graphics design that made for each promotional material are considered to have been able to deliver a message to anyone who saw it and could represent the purpose and objectives of the exhibition

The next attribute is Booth/stand management. The indicators of this attribute are layout plan of exhibition space, exhibition security, booth distribution, booth location selection, booth quality, booth cleanliness, booth facilities and availability of additional facilities.

The assesment by respondents' expectation towards the exhibition service quality in the booth/stand management attribute obtained a total score of 2808, considered as very important. While the respondents' perception towards the exhibition service quality in the booth/stand management attribute obtained a total score of 2416, considered as good. The majority of respondents agreed that the booth/stand management attribute provided by PT. Dyandra Promosindo has fulfilled their expectations. Twenty three years of experience in organizing exhibitions was reflected in the lack of complaints regarding technical issues related to booth management. The exhibitors appraised the process of bidding, selecting, marking, loading in, show day until loading out runs smoothly without any problems.

The technical processing process related to booth/stand management was assisted by an official stand contractor at the exhibition, PT.Samudera Dyan Praga. Thirty three years of experience handling thousands of national and international exhibitions, and from both domestic and foreign corporate clients, Samudra Dyan Praga is one of the best stand contractor company in Indonesia. The official stand contractor selection is also one of the added values in an exhibition, this is due to the booth designs displayed in the exhibition room can make the atmosphere more lively.

The next attribute is surrounding environment. It refers to the venue of exhibition. The indicators of this attribute are: Venue selection, quality, capacity, cleanliness, comfort, ease of transportation, location and distance of venues from the city center, conducive environment, and F\&B services.

The assesment by respondents' expectation towards the exhibition service quality in the surrounding environment attribute obtained a total score of 3148, considered as very important. While the respondents' perception towards the exhibition service quality in the physical environment management attribute obtained a total score of 2567, considered as good.

Regarding of planning an exhibition, the venue is the most important factor that must be prepared; the availability, capacity, facilities and suitability of the venue itself with the concept of the exhibition to be held. 
In organizing the Indonesia Future City \& REI Mega Expo 2017, the Indonesia Convention Exhibition (ICE) chosen for the venue. Located in the BSD City Tangerang business district, as well as being the largest capacity venue in Indonesia. Othr than that, ICE was chosen because of the complete facilities and reliability of the management. With a total area of 220,000 sqm that can be used, consisting of 10 indoor exhibitions halls covering an area of 50,000 $\mathrm{m} 2$, outdoor exhibition space covering $50,000 \mathrm{~m} 2$, convention hall covering $4,000 \mathrm{~m} 2$, and $12,000 \mathrm{~m} 2$ pre-function lobby, indeed this is tempting for MICE industry players in Indonesia to hold an event there.

ICE is managed directly under Deutsche Messe, a company engaged in the field of Venue Management and Professional Exhibition Organizer from Germany and has an international reputation as well as business units in various countries.

With the image and reputation the company has, the exhibitors agreed that the services provided in the surrounding environment attribute were fairly good. The point of concern of this attribute was the location \& distance of the venue from Jakarta City. The exhibitors complained about the distance of the venue being one of the obstacles for the exhibitors themselves to come to the exhibition, as well as potential visitors who might think twice about coming to the exhibition. PT. Dyandra Promosindo actually has anticipated this by providing free shuttle services from various malls in the cities of Jakarta, Depok \& Bekasi, in order to facilitate accessibility to the exhibition venue, However the exhibitors thought that it has not been maximized to attract visitors to use the service, so that the quality still needs to be improved.

The next attribute in the exhibition service quality is service information. This attribute is closely related to important informations to be given to exhibitors. The indicators contained in this attribute are: Constraints of information, completeness of information, ease of obtaining information and timeliness of information delivery.

The assesment by respondents' expectation towards the exhibition service quality in the service information attribute obtained a total score of 1279 , considered as very important. While the respondents' perception towards the exhibition service quality in the service information attribute obtained a total score of 2567 , considered as fairly good.

During the planning and organizing of the exhibition, various ways have been carried out by PT Dyandra Promosindo as the organizer to facilitate communication with the exhibitors, such as: held a technical meeting to give and discuss technical issues of exhibition operations, made exhibition manuals for the exhibitors as guidelines in participating in the exhibition, madechat groups on social messengers such as Whatsapp to facilitate the communication process before and during the exhibition, held meetings with exhibitors every day during the exhibition to discuss the difficulties faced and find solutions that benefit both parties, provide a help desk to facilitate services, and assigned special officers to convey information to the exhibitors.

Based on the results, some exhibitors only complained about some misunderstandings and inaccuracies that occurred during the exhibition, but they could still be tolerated, and of course this should be an important note and input for PT Dyandra Promosindo in managing the upcoming exhibition

The last attribute in the exhibition service quality is service personnel. this attribute is closely related to service personnel provided to exhibitors, both before and during the exhibition. The indicators of this attribute are: Registration procedures, service friendliness, speed and responsiveness to answering requests, activeness in providing assistance, performance of the organizers, attention of the organizers, and appearance of the organizers.

The assesment by respondents' expectation towards the exhibition service quality in the service personnel attribute obtained a total score of 2200, considered as very important. While the respondents' perception towards the exhibition service quality in the service personnel attribute obtained a total score of 1778 , considered as fairly good.

PT Dyandra Promosindo is truly aware that in the preparation and holding an exhibition, it needs to be supported by the readiness of human resources in providing services. In addition, various SOPs (Standard Operating Procedures) must be well understood by the employees of the exhibition. The exhibitors agreed that the services provided by employees met their needs well.

\section{Exhibitors Satisfaction}

Figure 1

Cartesius Diagram of The Perception \& Expectation of Exhibitors's Satisfaction

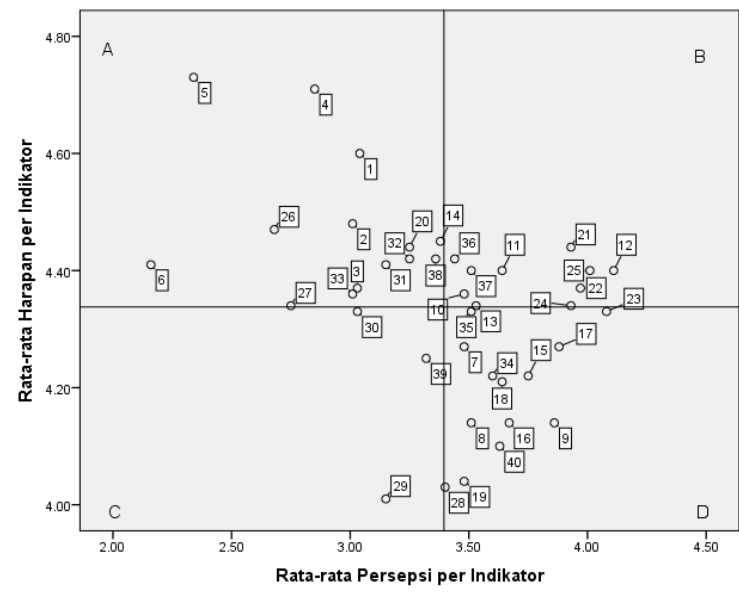

Based on the Cartesius diagram above, there are 4 (four) quadrants which divide the size of the exhibitors' 
satisfaction at the Indonesia Future City \& REI Mega Expo 2017 based on their perceptions and expectations.

These are the quadrant categories:

1. Quadrant A (Main Priority) which shows the factors that are considered to affect the satisfaction of exhibitors and must be the main priority (Unsatisfied and Very Important). In this quadrant there are 14 indicators:

1) Promotion through print media (No. 1)

2) Promotion via invitation (No. 2)

3) Promotion through printed media (No. 3)

4) Promotion via internet (No 4)

5) Number of visitors (No. 5)

6) Number of Transactions (No 6)

7) Selection of booth locations (No 14)

8) Venue selection (No. 20)

9) Ease of Transportation from and to the venue (No. 26)

10) Selection of venues seen from distance to the city center (No 27)

11) Complete information provided (No 31)

12) Ease of getting information (No. 32)

13) Timeliness of information delivery (No. 33)

14) Performance of exhibition organizers (No. 38)

Based on the explanation above, quadrant A shows that there are 14 (fourteen) aspects of satisfaction that are have not meet the expectations of the exhibitors, so that the above aspects really need to get priority to be handled by the organizers. In quadrant $\mathrm{A}$ it is concluded that the exhibitors'perception towards satisfaction is still too low where the exhibitors' expectation towards satisfaction show considered as very important, thusit need to be considered and improved. This issue must be paid more attention by the organizers because the exhibition is considered unable to satisfy the exhibitors.

2. Quadrant B (Maintain Achievement) shows the main factors that have been successfully implemented and must be maintained (Very Satisfied and Very Important). In this quadrant there are 10 indicator:

1) Overall ideas \& concepts design (No. 10)

2) exhibition booth planning (No. 11)

3) Exhibition Layout (No. 13)

4) Venue Quality (No 21)

5) Venue Capacity (No 22)

6) Venue Facilities completeness (No 24)

7) Venue Comfort (No 25)

8) Speed and responsiveness of the organizer (No 36)

9) The organizer's activity in helping (No 37)

Based on the explanation above, quadrant B shows that there are 10 (ten) aspects of satisfaction that have satisfied the exhibitors of REI Expo, which explained that in quadrant $\mathrm{B}$, the perceptions and expectations of exhibitors towards the service quality can be fulfilled. This must be considered and further enhanced by the organizers in order to maintain the satisfaction of the exhibitors who will participate and re-attend the exhibition every year although there is still a gap between aspects of perception and aspects of expectations. In general, these aspects has satisfied the exhibitors.

3. Quadrant C (Lowest Priority) shows factors that are less important for customers (exhibitors) (Unsatisfied and Not Important). In this quadrant, there are 3 indicators:

1) F \& B Service (No 29)

2) Reliability of information provided by the organizer during the exhibition (No. 30)

3) Attention given by the organizer (No 39)

Based on the explanation above, quadrant $\mathrm{C}$ shows that there are 3 (three) aspects of satisfaction that are considered not too important and considered not to have much effect on satisfaction but the exhibitors consider these aspects less satisfactory, which explained that in the quadrant $\mathrm{C}$, aspects of perception and expectations are considered ordinary. But it does not rule out the possibility that the exhibitors need to feel satisfaction towards the aspects above because they are still related to the exhibitions will be attended by exhibitors in the future.

4. Quadrant D (Excessive Category) shows factors that are less important in their affects but their implementation is considered too excessive (Very Satisfied and Not Important). In this quadrant there are 13 indicators:

1) Design of promotional material (No 7)

2) Venue decoration design (No. 8)

3) Exhibition logo design (No. 9)

4) Booth quality (No. 15)

5) Convenience booth (No 16)

6) Cleanliness of the booth (No 17)

7) Booth Facilities (No 18)

8) Availability of additional facilities (No 19)

9) Cleanliness of the venue (No. 23)

10) Environmental situation (No. 28)

11) Registration procedure (No 34)

12) Hospitality service (No 35 )

13) Appearance of the organizer (No. 40)

Based on the explanation above, quadrant $\mathrm{D}$ shows that there are 13 (thirteen) aspects of satisfaction that are considered not too important and considered not to have much effect on satisfaction but the exhibitors considered this aspect very satisfying, which explained that in this quadrant $\mathrm{D}$, the aspects of perception and expectation are considered ordinary but the exhibitors; perception shows that the implementation is excessive. This was caused by the exhibitors that considered the aspects were not 
very important even though the organizers implemented it very well.

D. The Effect of Exhibition Service Quality towards Exhibitors Satisfaction

Statistical tests were used to obtained several results related to the coefficient of determination, $t$ test (partial test), and F test (simultaneous test) by SPSS version 23.00.

The result showed that $r^{2}$ value is $\mathbf{0 . 6 4 8}$, that means the variable quality of exhibition services consisting of exhibition marketing, exhibition design, booth / stand management, surrounding environment, service information and employee services affect exhibitor satisfaction by $\mathbf{6 4 . 8 \%}$, while the remaining $\mathbf{3 5 . 2 \%}$ is affected by other factors not observed in this study.

The magnitude of the influence of the exhibition service quality variable on the satisfaction of exhibitors mean that the organizers must always pay attention to and maintain the quality of the exhibition services provided to the exhibitors. This is because the exhibition business can be held properly if there are players who consist of an organizer, exhibitor and visitor. The satisfaction of the three key players in the exhibition business will certainly determine the success of an exhibition itself. If we refer to the essence of the exhibition business the organizer plays a big role in bringing together the appropriate exhibitors and visitors, so mutually beneficial for all parties will be achieved.

Exhibitor and visitor are customer for an organizer. With more and more organizers arose in Indonesia, the competition will be even tighter. Moreover, with the inclusion of foreign organizer companies to the country through mergers and acquisitions will make it harder to compete. In this case, the added value from an organizer is how the company can provide better quality services to satisfy its customers.

The satisfaction of exhibitors after participating in an exhibition will certainly affect the next exhibitions. The more exhibitors who are satisfied with the exhibition services provided, will make them participate again in the next exhibition, and it will be easier for an organizer to manage it. When that happens, it can be ascertained that the profits for the organizer can be achieved.

Furthermore, based on the results of the T Test (Partial test), the results and descriptions indicate that the attributes of exhibition service quality in the form of exhibition marketing and the surrounding environment had a significant effect on the satisfaction of exhibitors. While the attributes of exhibition design, stand / booth management, information on employee services and services have no significant effect on the satisfaction of exhibitors.

F Test Results (Simultaneous Test), based on the calculation results obtained p-value (sig) 0,000 . With $\alpha=0.05$, H0 is rejected and H1 is accepted, that means that the independent variables consisting of exhibition marketing, exhibition design, booth / stand management, physical environment, service information and employee services have a significant effect on satisfaction of exhibitors.

By accurately recognizing the attributes of exhibition service quality variable that has an affect on the satisfaction of the exhibitors, it can facilitate the organizer in planning and organizing an exhibition, in order to prepare better services to fulfill customers' expectations.

A. Conclusions

\section{CONCLUSION}

The conclusions based on the results of data analysis on "The Exhibition Service Quality and Their Effects on Satisfaction of Exhibitors" are as follows:

1. Based on descriptive analysis, respondents' expectation towards the exhibition service quality are considered as a very important, while respondents' perception towards et exhibition service quality considered as fairly good.

2. Based on the calculation, the result of the gap between the perception and expectation of respondents of exhibitors at the Indonesia Future City \& REI Mega Expo 2017 shows that exhibitors were not satisfied with the exhibition service quality provided by PT Dyandra Promosindo.

3. Based on the results of the analysis using the IPA (Importance Performance Analysis) there are 4 (four) quadrants which divide the exhibitor satisfaction measures at the Mega Expo 2017 Indonesia Future City \& REI Exhibition based on perceptions and expectations. Quadrant A (Main Priority; Not Satisfied \& Very Important) consisted of 14 indicators that must be a top priority for the organizer in improving the services provided. Quadrant B (Maintain Achievement; Very Satisfied \& Very Important) consisted of 10 indicators that must be maintained for the organizer in providing services to the exhibitors. Quadrant C (Lowest Priority; Not Satisfied \& Not Important) consisted of 3 indicators that must be an additional note for the organizer in providing services to the exhibitors. Quadrant D (Excessive Category; Very Satisfied \& Not Important) consisted of 13 indicators that must be included for the organizer in providing 
services to exhibitors at the upcoming exhibition.

4. Based on the results of the T Test (Partial Test) with the criteria if the p-value is $<0.05$ then H0 is rejected and $\mathrm{H} 1$ is accepted and vice versa. The quality of the exhibition service quality that partially affects satisfaction of exhibitors is exhibition marketing and the surrounding environment. While the quality attributes of exhibition service quality that has no partial effect on satisfaction of exhibitors are exhibition design, booth / stand management, employee service and service information.

Although partially the attributes of exhibition design, booth / stand management, service personnel and service information were not significantly influence the satisfaction of exhibitors, but simultaneously through $\mathrm{F}$ test of exhibition marketing, exhibition design, booth / stand management, surrounding environment, service information, and service personnel affect significantly. Based on the results of the determination coefficient, result of $\mathrm{r} 2$ is 0.648 . It shows that the exhibition service quality variable consisting of exhibition marketing, exhibition design, booth / stand management, surrounding environment, service information and service personnel affect exhibitor satisfaction by $64.8 \%$, while the remaining $35.2 \%$ is influenced by other factors not observed in this study. While the multiple linear regression equation that can be formed is $\mathrm{Y}=1,130+0,183 \mathrm{X} 1+0,091 \mathrm{X} 2+$ $0,035 \mathrm{X} 3+0,181 \mathrm{X} 4+0,045 \mathrm{X} 5+0,019 \mathrm{X} 6$

\section{B. Suggestions}

Based on the results of the research and conclusions above, the following suggestions can be given by the author as follows:

1. For PT Dyandra Promosindo

a. Based on the results of research on the quality of exhibition services, PT. DyandraPromosindo as the organizer of Indonesia Future City \& REI Mega Expo 2017, is expected to be able to improve the quality of the exhibition services provided, considering that the results in this study show that there is still a gap between the expectation and perceptions of the exhibition service quality.

b. Based on the results of research on the satisfaction of exhibitors, PT DyandraPromosindo is expected to pay more attention to indicators that can affect the satisfaction of the exhibitors participating in the exhibition. Some indicators that need to be improved and upgraded in quality that can be seen in quadrant A Cartesian diagram which is on page 87 , where there are 14 indicators that are considered important for immediate improvement in quality because they directly affect the satisfaction of exhibitors. When the exhibitors feel dissatisfied with the quality of the exhibition services provided by the organizer, this will affect their interest in returning to participate in the next exhibition. PT DyandraPromosindo is also expected to maintain the exhibition service quality provided that have been considered good in this research and satisfy the exhibitors both in terms of expectations and needs.

c. Based on the research on the effect of exhibition service quality on satisfaction of exhibitors, PT DyandraPromosindo is expected to improve the attributes of exhibition marketing and the surrounding environment because these two attributes have a partial effect on the satisfaction of exhibitors. For marketing attribute, organizer can use promotional strategies that are more effective and efficient in in order to attract customers who fit with the concept of the exhibition, such as sending direct mail and invitations to potential visitors who are highly potential to make transactions. Another method is by collaborating with companies / institutions / agencies in Jakarta and in terms of providing housing for their employees. As for the surrounding environment attribute is by choosing a venue that fits the concept of the exhibition. The selection of venue locations that are close to the city center and offices is felt to be more convenient for organizing events and can increase the number of visitors, especially towards the type of property exhibition.

\section{For PEO member of ASPERAPI}

a. The Professional Exhibition Organizer (PEO) who is member of ASPERAPI (Association of Indonesian Exhibition Companies) can make the dimensions, indicators and statements in this study as an instrument to measure the satisfaction of exhibitors participating in the exhibition on the quality of exhibition services provided by PEO.

3. For further research

a. Indicators and questions that used in the research can still be developed in accordance with the needs of each study, especially those relating to the types of exhibits that are different from those examined in this study. 
b. For furthermore study, it is expected to use other types of exhibits as objects and location of research, as well as adding variables regarding visitors.

\section{REFERENCES}

[1] Appleyard. J. (2005). How To Exhibit at Trade Fairs. How To Content. UK.

[2] Bowdin, M. G. (2004). Event Management, Oxford, Elsevier Butterworth.

[3] Bruhn, M. K., \& Hadwich, K. (2005). Managing the service quality of trade fairs. In M. Kirchgeorg (Ed), Trade show management: Planning, implementing and controlling of trade show, convention \& events (pp. 787-821). Wiesbaden, Germany: Gabler Verlag.

[4] Carman, J. M. (1990). Consumers perceptions of service quality: An assessment of SERVQUAL dimensions. Journal of retailing, 66, 3355.

[5] Chen, Yu-Fen., \& Mo, Huai-en. (2012). Attendees perspectives on the service quality of an exhibition organizer : A Case study of a tourism exhibition. Tourism Management Perspectives.

[6] Creswell, J. W. (2010). Research Design : Pendekatan Kualitatif, Kuantitatif dan Mixed. Pustaka Pelajar.

[7] Getz, D. (2008). Event Tourism: definition, evolution and research. Tourism Management, 29(3), 403-428.

[8] George, K. (2012). A model for assessing consumer perceptions of quality. International Journal of Quality and Services Science, 4(1), 175-188.

[9] Gofman, A., Moskowitz, H., \& Mets, T. (2011). Marketing museum and exhibitions:What drives the interest of young people. Journal of Hospitality Marketing and Management, 2(3), 3-22.

[10] Jin, X., Weber, K., \& Bauer, T. (2012). Relationship quality between exhibitors and organizers : A Perspective from Mainland China's exhibition industry. Tourism Management Perspectives.

[11] Jin, X., \& Weber, K., (2016) "Exhibition destination attractiveness organizers' and visitors' perspectives", International Journal of Contemporary Hospitality Management, Vol. 28 Issue: 12, pp.27952819 ,

[12] Jung, M. (2005). Determinants of Exhibition Service Quality as Perceived by Attendees, Journal of Convention \& Event Tourism.

[13] Karsono, D. (2016). Bisnis Pameran ala Dwi Karsono. Bee Media.

[14] Kesrul, M. (2004). Meeting, Incentive Trip, Confrence, Exhibition. Yogyakarta. Graha Ilmu.

[15] Kim, S. S., Sun, H. \& Ap, J. (2008). Is there competition in the exhibition market in Asia? Analysis of the positioning of major Asian exhibition host cities? Asia Pacific Journal of Tourism Research, 13, 205-227.

[16] Kusmayadi \& Sugiarto. (2000). Metodologi Penelitian dalam Bidang Kepariwisataan. Jakarta: PT. Gramedia Pustaka Utama.

[17] Kotler, P. (2003). Marketing Management, $11^{\text {th }}$ Edition. Prentice Hall Int'l, New Jersey, p.138

[18] Kotler, P. (2004). Principles of Marketing, Tenth Edition. Person Educational International

[19] Kozak, N. (2006). The expectations of exhibitor in Tourism, hospitality and travel industry. Journal of Convention and Event Management, 7 (3), 99-116.
[20] Lee, M., Seo, J., \& Yeung, S. (2012). Comparing the motives for exhibition participation: Visitor's versus exhibitor's perspectives. International Journal of Tourism Science, 12(3), 1-19.

[21] Lee, M. J., Lee, S., \& Joo, Y. M. (2015). The Effects of Exhibition Service Quality on Exhibitor Satisfaction and Behavioral Intentions. Journal of Hospitality Marketing \& Management.

[22] Lin, C. T., \& Lin, C. W. (2013). Exhibitor's Perspectives of Exhibition Service Quality, Journal of Convention \& Event Tourism, 14:4, 293308.

[23] Lin, C.T., \& Lin, C. W. (2013). Exhibitor perspectives of exhibition service quality, Journal of Convention \& Event Tourism, 14:4, 293308

[24] Lin, Y., Kerstetter, D., \& Hickerson, B. (2015). Developing a Trade Show Exhibitor's overall Satisfaction Measurement Scale. Tourism Travel and Research Association: Advancing Tourism Reserach Globally. 28.

[25] Noor, A. (2009). Manajemen Event. Alfabeta. Bandung.

[26] Parasuraman, A., Zeithaml, V.A., \& Berry, L.L. (1988). SERVQUAL: A Multiple item scale for measuring consumer perceptions of service quality. Journal of Retailing, 64 (1), 12-40.

[27] Parasuraman.Valarie.A.Z \& Berry. (1990). Delivering Quality. Service McMilan.

[28] Pearce, D. G. (2007). Supplier selection in the New Zealand inbound tourism industry. Journal of Travel and Tourism Marketing, 23 (1), 57-68.

[29] Rangkuti, F. (2002). Measuring Customer Satisfaction. Gramedia Pustaka Utama.

[30] Rainbolt, G. N., Beinfield, J. A., \& Loomis, R. J. (2012). Visitor selfreport behavior mapping as a tool for recording exhibition circulation, Visitor Studies, 15:2, 203-216.

[31] Roobe, D. (2000). Exposition \& Trade Show. John Wiley \& Sons. Canada

[32] Sashi, C. M., \& Perretty, J. (1992). Do trade show provide value?. Industrial Marketing Management 21. 249-255.

[33] Silalahi, U. (2012). Metode Penelitian Sosial. PT. Refika Aditama. Bandung.

[34] Siskind, B. (2005). Powerful Exhibit Marketing. John Wiley \& Sons. Canada.

[35] Smith, T. M., Hama, K., \& Smith, P. (2003). The effects of successful trade show attendance on future show interest: Exploring japanese attendee perspectives of domestics and offshore international events. The journal of business and Industrial Marketing, 18 (4/5), 403-418.

[36] Sugiyono. (2014). Metodologi Penelitian Kuantitatif \& Kualitatif dan R \& D. PT. Alfabeta. Bandung.

[37] Sugiyono. (2005). Metodologi Penelitian Administrasi. PT. Alfabeta. Bandung.

[38] Tafesse, W., Korneliussen, T., \& Skallerud, K. (2010). Importance Performance Analysis as a Trade Show Performance Evaluation and Benchmarking Tool. Journal of Convention \& Event Tourism.

[39] UFI, (2016). The Global Exhibition Industry Statistics.

[40] Whitfield, J., \& Webber, D. J. (2011). Which exhibition attributes creates repeat visitation. International Journal of Hospitality Management 30, 439-447.

[41] Wu, H. C., Cheng, C. C., \& Ai, C. H. (2016). A Study of Exhibition Service quality, perceived value, emotions, satisfaction and behavioral intentions. Event Management, Vol.20, pp. 565-591.

[42] Yuksel, U., \& Voola, R. (2010). Travel trade shows : Exploratory study of exhibitor perceptions. Journal of Business \& Industrial Marketing. 